\title{
TWEEDSMUIR PARK, BRITISH COLUMBIA
}

\section{A PLEA FOR PRESERVATION}

\section{By Genevieve Barteaux}

To understand the interior of British Columbia the reader must realize that the white man's history there is short, for Alex Mackenzie was the first white man to make his way overland to the Bella Coola Valley in 1793. Three years later, on his journey to the Pacific Ocean, he followed the Mackenzie River to Mackenzie Bay on the Beaufert Sea.

In 1874 Charles Horelzky explored the Dean Channel in his search for a suitable passage for a trans-continental railway. The first map of that area, which I have before me as I write, was compiled by Father A. G. Morice, an O.M.I. missionary, who came to Canada from France in 1894. This map is designated as the Map of New Caledonia. It shows Morice Lake as being one of the lakes in the circular chain of rivers and lakes out of which the Nechako River flows. Father Morice did himself proud when he named this lake "Morice". It is unrivalled for scenic beauty on this continent and is possibly the most beautiful lake in the world. On our present-day maps this lake is called Eutsuk Lake, and what was originally named Loring Lake to the north, is now known as Morice Lake. It was not until 1920 that this part of British Columbia was surveyed and added to the map of Canada.

In 1908 my father and I travelled over the Old Cariboo Road to Quesnel, and over the government telegraph trail to the Nechako Valley, which I was the first white child to reach. Our first camp was at Cluculz Lake, where the Indians from Thachek (now Stony Creek) were encamped for the spring fishing. They had never seen a white child before, but probably concluded that all children were alike, and that if the little stranger had red curly hair, it was interesting to find hair that could be pulled straight, but would go crooked as soon as one let it go. So I was made welcome and soon, like the other children, was eager and waiting to go along when the Indians took out the canoes to examine their nets. As they paddled they sang. To ride in a canoe while the Indians sang was a fine experience for any child and one that I shall always remember. To-day one misses the songs of the Indians as they tend their nets. The Indians no longer sing the songs of their forefathers, and soon their songs, like that way of life, will be forgotten.

Not finding any land to his liking around Cluculz Lake, my 
father took me on to the Nechako River where he pre-empted a homestead on the banks of the Necha-Big-Ko River, the Big River. The following year I christened the first steam boat to navigate its waters. But all this is past history. To-day that river has been killed at its source in the name of progress, and the greater part of the most beautiful park in Canada destroyed forever.

In March, 1936, a triangular piece of land of 5,400 square miles, 1,500 encircled by 270 miles of rivers and lakes, was set aside by the Provincial Government--dedicated to the pcople of Canada - and named Tweedsmuir Park, after Lord Tweedsmuir, then Governor-General. It was never to be touched by commerce, but to remain inviolate forever. Just seventeen years later the 1953 British Columbia Park list reads : "Tweedsmuir - This area, until lately one of the largest wilderness areas in North America, is now the site of an immense industrial development - the establishment of Canada's aluminium industry. No recommendation concerning recreational facilities can be made at this time." Our most beautiful park is to be used by the Aluminium Company of Canada, or Alcan as it is often called, as a hydro-electric power project.

When Lord Tweedsmuir saw this country, at that time largely unexplored and unmapped, he described it as "The land of the golden twilight on the rim of the great unknown ". It seems tragic that the chain of lakes and rivers surrounding the central 1,500 square miles of the park and known as the Great Circle should be like the stag with the beautiful horns in the fable, in that its pride proved its undoing. For out of this chain of lakes and rivers flows the Nechako River. Man conceived the idea of damming the Nechako, and raising the level of the lakes and rivers until the water flowed in the opposite direction, thus forming the second largest hydro-electric power project in the world. Soon "Aluminium or Starvation" became the election slogan.

Later, at Parliament Buildings in Victoria, on 31st October, 1949, a hearing on the application by the aluminium company was held before Major Farrow, Comptroller of Water Rights. I went to the hearing expecting to hear qualified people plead for the park from an aesthetic point of view. There were able men there for the fisheries and a brief was presented on the possible influence of the Nechako dam project on the wild life resources of the area. There was no one to plead for the park. I did my best. I asked if the people there who had seen the park would hold up their hands. Six did so. I said that in another fifty 




A MOOSE IN TWHaDSMUIR PARK.

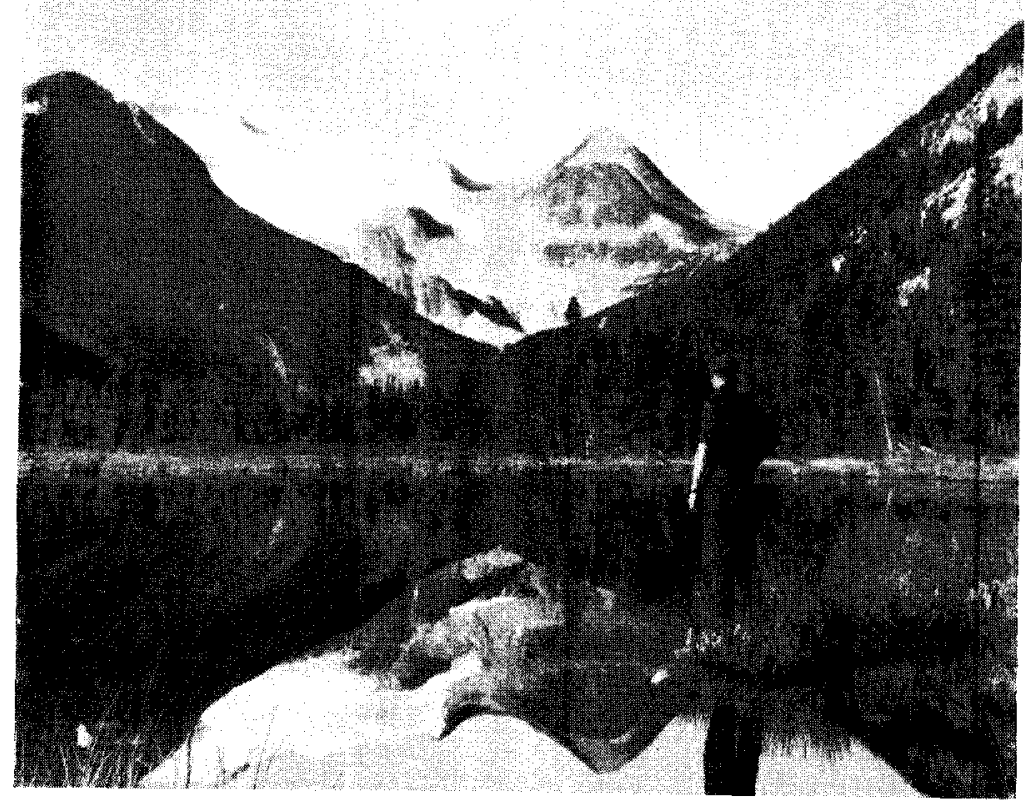

GLACIER VALLEY NEIR MYSTERY FALLS. 
years probably all Canadians would know about Tweedsmuir Park. I pointed out that the most beautiful park in Canada was being destroyed, merely to make money for someone.

I felt sick afterwards that I had not done better. Major

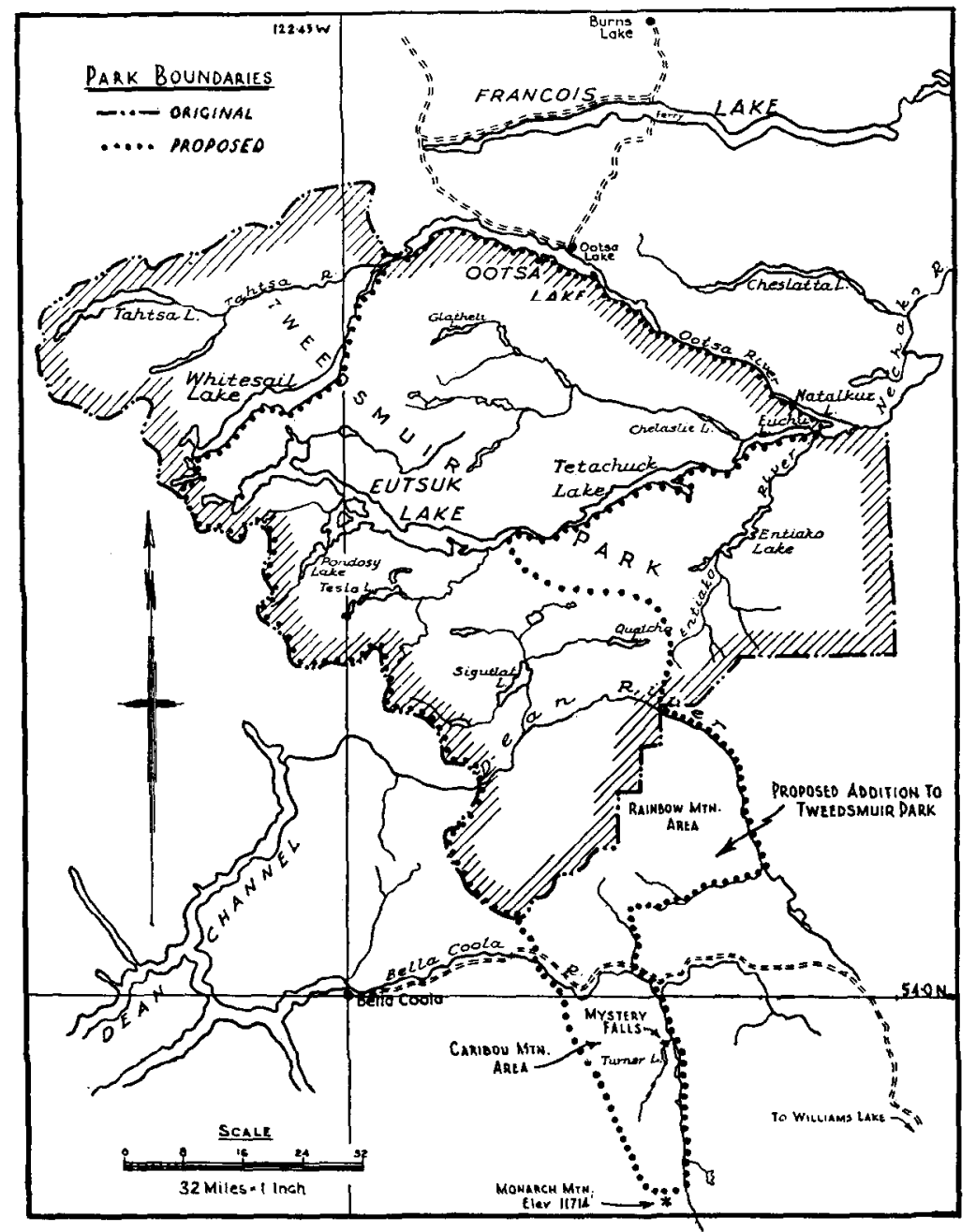

Farrow granted the licence. He tried to reconcile me by saying that he was sure that the devastation would not be as great as I feared-that Eutsuk, the most beautiful lake in the chain, would not be touched. He added that I could not stop the wheels of progress. According to the licence issued, Alcan was to clear 
and make usable to water level, all public roads and trail ends up to a total cost ; but not to exceed $\$ 250,000$-in an area of 5,400 square miles.

Now the dam is in. The northern entrance to the park has gone. The shore line of Ootsa Lake is a ghastly mess of submerged trees, roots, and debris. As the watcr continues to rise, each lake and river in the Great Circle with the exception of Eutsuk, will be fringed with dead and submerged trees, a monument to man's stupidity and greed. The flooded part may as well be written off as a park for ever.

Is this the end? Cannot anything be done to save part, at least, of the park for wild life and for the enjoyment of humanity? It can. Eutsuk Lake will not be touched by the flooding and between its northern shores and the flooded land of the Ootsa, a wild life sanctuary can still be established. The north-west and eastern ends of the park are lost, but to compensate for them an addition is suggested. This new area would bring a long tongue of the park southward to Monarch Mountain, with a bulge north-eastwards from the tongue to include the Rainbow Mountains. (See map.)

The new Tweedsmuir Park would be less than half the size of the old one but it would have features to compensate for what has been lost. Let us briefly consider some of these.

The wild life sanctuary in the north would include many small lakes and creeks, with suitable habitats for ruffed grouse, waterfowl, and beaver. Its altitude lies between 2,600 and 7,000 feet and there would be sufficient range for moose and deer in both summer and winter. Eutsuk Lake itself, 55 miles long, offers some of the most impressive scenery in the world, snowcapped mountains, creeks, and waterfalls.

In the proposed southerly addition to the park stand Anakim Peak, Tsitsut Peak, and the Rainbow Mountains with their large, gentle sub-alpine valleys and meandering streams.

The entrance to the park would be by steamer from Prince Rupert or Vancouver to Bella Coola and then by motor. Alternatively one could enter from the south-east along the old secondary road by way of Williams Lake.

A very popular trip would be to Mystery Falls. This circular route not only skirts large glaciers and crosses high mountains, but passes through a grove of willow trees so dense that the sunlight can barely filter through. After a few hours of steep climbing, during which one row of peaks after another comes slowly into view, the timber growth of sub-alpine country is reached. 
After camping in an alpine valley, the visitor continues to climb to the head of an alpine pass. From here, the land formation that has caused the Mystery Falls can be studied in detail, while directly across the valley a stream of milky-white water issues from a glacier. A sharp descent into the stream bottom leads to a beautiful camp site beside a small lake, in which the peaks and glaciers at the head of the valley are clearly mirrored.

Coming out on the shore of Turner Lake the visitor sees the river issuing from it disappear into the huge chasm of Mystery Falls a hundred yards away. Here the lip of the canyon offers many vantage points, but it is impossible to realize the full immensity of this 1,200 foot waterfall until reaching a promontory that allows a view both up and down the canyon. The water spills over the lip in a clean break, forming twin streams, which re-unite several hundred feet below. The ribbon of water is lost from sight in the depths of the gorge, where several hundred feet are hidden, obscured by heavy shadows and spray. This is the highest sheer waterfall in Canada.

In sharp contrast to the Rainbow Mountains, there rises to the west a peak draped with glaciers and resounding with ice falls all summer. The Indians call it Tzeelsaytsul, that is "Thunder Mountain ". Then comes Mount Stupendous, named by that dour Scot, Alex Mackenzie, 161 years ago.

Another outstanding mountain range is the Cariboo Mountains, situated between the inaccessible Coast Mountains and the low rounded hills of the interior. Steep timbered sides rise 4,000 feet from the main river bottoms to a timbered shelf. On this rests Turner Lake, with meadows, patchy snow fields, tumbling glacier streams, and further small lakes ranging in colour from sky-blue to deep viridian.

Shall all this beauty disappear? It can be saved if we Canadians have the vision to incorporate it into a park. This time there must be no mistake. The old park was Class "B". This new one must be a Class "A " Provincial Park, managed by a special department set up to administer recreation resources and defined in an Act. Then Canadians can really hope that Tweedsmuir Park will be inviolate for ever. 